\title{
Monadelpha (Euphorbiaceae, Plukenetieae), a new genus of Tragiinae from the Amazon rainforest of Venezuela and Brazil
}

\author{
Lynn J. Gillespie', Warren M. Cardinal-McTeague ${ }^{1,2}$, Kenneth J. Wurdack ${ }^{3}$
}

I Research \& Collections, Canadian Museum of Nature, P.O. Box 3443, Station D, Ottawa, Ontario, K1P 6P4, Canada 2 Agriculture and Agri-Food Canada, Ottawa Research and Development Centre, 960 Carling Ave, Ottawa, Ontario, K1A 0C6, Canada 3 Department of Botany, National Museum of Natural History, Smithsonian Institution, MRC-166, P.O. Box 37012, Washington DC 20013-7012, USA

Corresponding author: Lynn J. Gillespie (lgillespie@nature.ca)

Academic editor: D. Geltman | Received 2 October 2020 | Accepted 20 November 2020 | Published 8 December 2020

Citation: Gillespie LJ, Cardinal-McTeague WM, Wurdack KJ (2020) Monadelpha (Euphorbiaceae, Plukenetieae), a new genus of Tragiinae from the Amazon rainforest of Venezuela and Brazil. PhytoKeys 169: 119-135. https://doi. org/10.3897/phytokeys.169.59244

\begin{abstract}
Monadelpha L.J.Gillespie \& Card.-McTeag., gen. nov., is described as a new member of Euphorbiaceae tribe Plukenetieae subtribe Tragiinae, to accommodate Tragia guayanensis, a species known from western Amazonas, Venezuela and, newly reported here, from Amazonas, Brazil. The genus is unique in the subtribe for having 5-colpate pollen and staminate flowers with filaments entirely connate into an elongate, cylindrical staminal column terminated by a tight cluster of anthers. Phylogenetic analyses based on nuclear rDNA ITS and sampling 156 accessions across the diversity of Tragiinae (all 12 genera and 77 of -195 species) also support Monadelpha as a distinct lineage that is separate from Tragia. A revised key to the genera of Tragiinae in South America and Central America is provided.
\end{abstract}

\section{Keywords}

Brazil, ITS, molecular phylogeny, Plukenetieae, pollen, Tragia, Venezuela

\section{Introduction}

Members of tribe Plukenetieae are morphologically unusual within Euphorbiaceae for frequently possessing stinging hairs, twining vine or liana habit, and colorful pseudanthia (in Dalechampia). The tribe is characterized by apetalous flowers, valvate staminate

Copyright Lynn J. Gillespie et al. This is an open access article distributed under the terms of the Creative Commons Attribution License (CC BY 4.0), which permits unrestricted use, distribution, and reproduction in any medium, provided the original author and source are credited. 
sepals, and undivided styles that are basally to entirely connate. Plukenetieae contains three subtribes (i.e., Dalechampiinae, Plukenetiinae, Tragiinae), of which Tragiinae is the largest and most diverse, with 12 genera and -195 species as currently circumscribed (Webster 2014; with updates by Medeiros et al. 2013; Cardinal-McTeague and Gillespie 2016) (Table 1). Subtribe Tragiinae is distinguished from Plukenetiinae by stinging hairs and consistently 3-locular ovaries and eglandular leaves, and from Dalechampiinae by racemose or thyrsoid inflorescences rather than bibracteate pseudanthia (Gillespie 1994a; Webster 2014).

Among Tragiinae, the most species-rich genus is Tragia, which includes -150 species, whereas the other 11 genera are much smaller with only one to 11 species each (Table 1). The complex infrageneric classification of Tragia currently comprises two subgenera, six sections (including sect. Monadelphae L.J.Gillespie), one species group, and two unplaced species (Table 1). A single species has been segregated as T. subg. Mauroya (Leandri 1971); however, our preliminary research suggests this species is closely allied with sect. Agirta and does not warrant subgeneric status. All other species belong to T. subg. Tragia. Three other sections, sects. Leptorhachis (Klotzsch) Müll. Arg., Leucandra (Klotzsch) Müll.Arg. and Ratiga Müll.Arg., that are sometimes considered distinct are included here within sect. Tragia, a position supported by pollen (Gillespie 1994a) and molecular studies (Cardinal-McTeague and Gillespie 2016). Tragia species exhibit very diverse pollen and floral morphology that is correlated in part with its infrageneric classification (Gillespie 1994a, b). The genus was suggested to be highly paraphyletic based on this morphological diversity (Gillespie 1994a), which is confirmed by recent molecular phylogenetic studies focused on Plukenetieae (Cardinal-McTeague and Gillespie 2016). Three sections of Tragia, sects. Bia (Klotzch) Müll. Arg., Ctenomeria (Harv.) Benth., and Zuckertia (Baill.) Müll.Arg., were recently reinstated as genera (Webster 2007, 2014; Medeiros et al. 2013) based on inferences from pollen morphology (Gillespie 1994a), floral morphology, and preliminary molecular results (Wurdack et al. 2005), and are supported by our more in-depth molecular study (Cardinal-McTeague and Gillespie 2016).

One of the most unusual species of Tragia is T. guayanensis L.J.Gillespie, which was considered so distinct as to merit its own monotypic section, Monadelphae L.J.Gillespie (Gillespie 1994b). The species is characterized by two features unique in Tragiinae: 5-colpate pollen and filaments entirely connate into an elongate cylindrical staminal column (Figs 1, 2). All other Tragia species have 3-aperturate pollen, which is mostly 3-colpate, sometimes 3-porate or with three poorly defined apertures (Table 1), with the exception of 4-colpate in T. rubiginosa Huft (preliminary observations in Gillespie $1994 b$ ), a species unplaced in the sectional classification. Filaments in staminate flowers of Tragia are usually distinct to sometimes basally connate. The only other species having filaments entirely connate is T. lassia Radcl.-Sm. \& Govaerts of sect. Lassia, which has stamens connate into a very short disc-like structure (Baillon 1858: pl. 4, figs 24, 25; pers. obs.), and very different from that of T. guayanensis. When describing T. guayanensis, Gillespie (1994b) suggested the species was distinct and not closely related to any other Tragia species. Nevertheless, she maintained the species within 
Table I. Tragiinae genera and infrageneric taxa of Tragia: species number, geographic distribution, and pollen morphology. Adapted from Cardinal-McTeague and Gillespie (2016) with pollen characters from Gillespie (1994a, 1994b) and taxonomic updates from this paper.

\begin{tabular}{|c|c|c|c|c|}
\hline Genus/section & spp. \# & Geographic distribution & Pollen apertures & Pollen tectum \\
\hline Acidoton Sw. & 5 & Hispaniola, Jamaica & inaperturate & rugulate \\
\hline Bia Klotzsch & 5 & Costa Rica to South America & inaperturate & $\begin{array}{l}\text { foveolate-fossulate } \\
\text { or finely reticulate }\end{array}$ \\
\hline Cnesmone Blume & 11 & SE Asia & weakly 3-colpate & punctate \\
\hline Ctenomeria Harv. & 2 & South Africa & weakly 3-aperturate & $\begin{array}{l}\text { finely foveolate- } \\
\text { reticulate }\end{array}$ \\
\hline Gitara Pax \& K.Hoffm. & 1 & Central and South America & 3-colpate & $\begin{array}{l}\text { finely foveolate- } \\
\text { reticulate }\end{array}$ \\
\hline Megistostigma Hook.f. & 5 & SE Asia & $\begin{array}{c}\text { weakly } 3 \text {-colpate to } \\
\text { inaperturate }\end{array}$ & punctate \\
\hline $\begin{array}{l}\text { Monadelpha L.J.Gillespie \& Card.-McTeag., } \\
\text { gen. nov. }\end{array}$ & 1 & $\begin{array}{l}\text { Venezuela (Amazonas), Brazil } \\
\text { (Amazonas) }\end{array}$ & 5-colpate & foveolate \\
\hline Pachystylidium Pax \& K.Hoffm. & 1 & SE Asia & weakly 3-porate & punctate \\
\hline Platygyna P.Mercier & 7 & Cuba & inaperturate & $\begin{array}{l}\text { reticulate or } \\
\text { rugulate }\end{array}$ \\
\hline Sphaerostylis Baill. & 2 & Madagascar & unknown & unknown \\
\hline Tragia L. & -150 & Pantropical to warm temperate & & \\
\hline sect. Agirta Baill. & 5 & Madagascar & unknown & unknown \\
\hline sect. Lassia (Baill.) Müll.Arg. & 2 & Madagascar & 3-colpate & reticulate \\
\hline sect. Leptobotrys (Baill.) Müll.Arg. & 2 & SE USA & weakly 3-porate & punctate \\
\hline sect. Tagira Müll.Arg. & 82 & Africa, Madagascar, S Asia & 3-colpate & reticulate \\
\hline sect. Tragia & 53 & $\begin{array}{l}\text { S USA to South America, } \\
\text { Caribbean }\end{array}$ & 3-colpate & intectate-baculate \\
\hline Australian species group & 3 & Australia & 3-porate & punctate \\
\hline T. biflora Urb. \& Ekman (unplaced) & 1 & Hispaniola & unknown & unknown \\
\hline T. rubiginosa Huft (unplaced) & 1 & Venezuela & 4-colpate & punctate \\
\hline subg. Mauroya Leandri & 1 & Madagascar & weakly 3 -aperturate & finely reticulate \\
\hline Tragiella Pax \& K.Hoffm. & 4 & E and S Africa & 3-colpate & reticulate \\
\hline Zuckertia Baill. & 2 & Mexico, Central America & 3-colpate & finely reticulate \\
\hline
\end{tabular}

Tragia in its own section pending further study and anticipating that a major reclassification along phylogenetic lines would be necessary.

Here we present molecular phylogenetic results placing $T$. guayanensis within subtribe Tragiinae that supports its recognition as a distinct genus. The new genus Monadelpha is described for T. guayanensis based on its unique pollen and floral morphology and isolated phylogenetic position within Tragiinae. This is the first of several contributions towards a new phylogenetic classification of subtribe Tragiinae.

\section{Material and methods}

\section{Molecular phylogeny}

To determine the phylogenetic relationships of Monadelpha, we sequenced and analyzed the Internal Transcribed Spacer (ITS) region (including complete ITS1, 5.8S, and ITS2, and flanking portions of $18 \mathrm{~S}$ and 26S) of nuclear rDNA. ITS has been 
shown to provide good resolution of Tragiinae in the prior studies (e.g., CardinalMcTeague and Gillespie 2016; Cardinal-McTeague et al. 2019) from which our core taxon sampling is drawn and presents few alignment problems across genera. Orthologous plastid data could not be recovered from the degraded Monadelpha sample, but the limited phylogenetic resolution of the more slowly evolving plastid loci is established and their addition would be unlikely to change our findings. Our taxon sampling of 156 accessions included 77 of -195 species of Tragiinae (39\% of total diversity) with representatives of all 12 Tragiinae genera and seven of the eight sections/species groups in Tragia (excluding the Madagascan subg. Mauroya, only known from its type collection of $T$. ivohibeensis Leandri). Due to unusually high GC content in the close relatives of Tragiinae (which results in challenging DNA alignments and recovers some questionable relationships; Cardinal-McTeague, unpublished data), we rooted the tree using three accessions from the sister clade of Plukenetieae, which contains tribes Bernardieae and Caryodendreae (Wurdack et al. 2005; Cervantes et al. 2016).

Extractions of genomic DNA, fluorescent Sanger sequencing, and contig assembly for the ITS sequences followed the protocols of previous molecular studies in Plukenetieae (Cardinal-McTeague and Gillespie 2016; Cardinal-McTeague et al. 2019). The paratype of T. guayanensis (Williams 14990, US) was sampled and sequenced at the Smithsonian separately from all other new data, under more stringent conditions for degraded museum samples following protocols in Dorr et al. (2018). That specimen is well preserved and the data appear authentic based on appropriate negative controls and unique phylogenetic placement. The sequences were aligned using the auto-select algorithm of MAFFT ver. 7.450 (Katoh and Standley 2013) in Geneious ver. 11.1.5 (BioMatters, Auckland, New Zealand), and the optimal model of nucleotide evolution was ranked by AIC (Akaike Information Criterion) using default search parameters across three substitution schemes in jModeltest2 ver. 2.1.6 on XSEDE (Darriba et al. 2012; Miller et al. 2010). Subsequent analyses were conducted on all data in the alignment and potentially ambiguous regions were few.

We estimated a phylogenetic tree using Bayesian inference with MrBayes ver. 3.2.6 on XSEDE (Ronquist et al. 2012), executing an (MC) ${ }^{3}$ analysis with two runs of 3 million generations and sampling every 1000 generations, using the optimal model of nucleotide evolution on an unpartitioned alignment (remaining parameters as default). Runs were considered converged if ESS (effective sample size) of each parameter were $>500$ in Tracer ver. 1.7 (Rambaut et al. 2018), and if PSRF (potential scale reduction factor) and the standard deviation of split frequencies were close to 1.0 and $<0.005$, respectively, as determined by the MrBayes output. A $50 \%$ majority rule consensus tree was calculated following a $25 \%$ burn-in, resulting in Bayesian posterior probability $(\mathrm{PP})$ values based on posterior distribution of 4500 trees from the combined runs. For an additional estimate of branch support, we inferred maximum likelihood bootstrap percentages (MLBP) using 1000 rapid bootstrap replicates under default parameters with RAxML-HPC ver. 8 on XSEDE (Stamatakis 2014). In the Results, we interpret strong branch support as PP $>0.95$ and MLBP $>85$. Discussion 
of the subclades (T1-T10) follows the naming convention of Cardinal-McTeague and Gillespie (2016) with minor adjustments.

\section{Data resources}

The data underpinning the analyses reported in this paper (DNA alignment and resulting Bayesian tree) are deposited in the Dryad Data Repository at https://doi. org/10.5061/dryad.5hqbzkh4d.

\section{Morphology}

Specimens were examined at CAN and US, on loan from MO, NY, and P (herbarium acronyms following Index Herbariorum (http://sweetgum.nybg.org/science/ih/), and from other herbaria via online images in the Global Biodiversity Information Facility (GBIF.org 01 Oct 2020 Occurrence Download https://doi.org/10.15468/dl.upmgky). The key was adapted from Gillespie (1994b), modified and updated based on examination of specimens and the following references: Mulgura de Romero and Gutierrez de Sanguinetti (1989); Radcliffe-Smith (2001); Medeiros et al. (2013); Steinmann and Ramírez-Amezcua (2013); Cardinal-McTeague and Gillespie (2016); Webster (2014).

\section{Phylogenetic results}

Our 159-terminal (80 taxa) ITS dataset, including 55 new sequences, had an aligned length of 795 characters (410 variable, 353 parsimony informative [44\%], 0.7\% missing data), and GTR $+\mathrm{I}+\mathrm{G}$ was identified as its optimal model of nucleotide evolution. Bayesian and ML analyses revealed very similar results. The $50 \%$ majority rule Bayesian topology was well resolved with most clades strongly supported by PP and MLBP (Fig. 3).

The phylogeny is divided into two major clades with strong to moderate support, the Old World Tragiinae clade (T1-T3) and the New World Tragiinae clade (T4-T10). The resolution of subclades T1-T3 was strongly supported, with subclade T1 (Ctenomeria) sister to T2 (Cnesmone, Megistostigma) + T3 (Tragia sect. Tagira, embedded with T. sects. Agirta and Lassia, and Tragiella). Subclades T4-T10 were mostly strongly supported, with the exception of the modified subclade T6/9, which includes the new genus Monadelpha with moderate support (PP =0.92, MLBP $=56$ ). The New World Tragiinae clade contains a small successive grade of subclades T4 (Bia) and T5 (Acidoton, Platygyna) that culminates into the strongly supported Core New World Tragiinae clade (T6-T10). This core clade comprises a weakly supported clade (PP = 0.90, MLBP $<50$ ) with three distinctive subclades, T6/9 (Gitara, Monadelpha, and Zuckertia) sister to T7 (Tragia sect. Leptobotrys) + T8 (Australian Tragia, Pachystylidium, and Sphaerostylis), which together are sister to the large subclade T10 (Tragia sect. Tragia). Monadelpha is on a long branch, moderately supported as sister to Zuckertia + Gitara (PP $=0.92$, MLBP = 56), and well separated from Tragia and other Tragiinae genera. 


\section{Discussion}

The phylogenetic relationships of Tragiinae recovered here largely agree with previous phylogenetic analyses of Plukenetieae based on ITS and plastid $p s b A-t r n H$ data (Cardinal-McTeague and Gillespie 2016). Our increased Tragiinae taxon sampling (77 here compared to 50 previously) improved both resolution and support, despite including only ITS data. A noteworthy difference is the revised placement of Gitara (subclade T9, formerly weakly supported as sister to Tragia sect. Tragia, T10; Cardinal-McTeague and Gillespie 2016), which is here strongly supported as sister to Zuckertia (T6), with Monadelpha sister to both of them. Monadelpha is an isolated lineage, clearly distinct from New World and Old World clades of Tragia. Support for its relationship with Gitara and Zuckertia (subclade T6/9) is not strong, which suggests that its position on the phylogeny may not be stable and could vary with additional sequence data. Inclusion of the Monadelpha ITS sequence in a broader analysis of Plukenetieae that sampled six loci (nuclear ribosomal ETS, ITS; low copy KEA1, TEB; plastid matK, $n d h F$; results not shown) recovered similar results with strong support for subclade T6/9, the inclusion of Monadelpha in subclade T6/9, and with weak support for generic relationships therein (Cardinal-McTeague et al., unpublished).

The 5-colpate pollen of Monadelpha is unique among Plukenetieae. All other Plukenetieae have 3-aperturate or inaperturate pollen, with the exception of T. rubiginosa (discussed below). Among New World Tragiinae, Gitara, Zuckertia, and Tragia sect. Tragia pollen is 3-colpate, whereas pollen of Acidoton, Bia, and Platygyna is inaperturate, and T. sect. Leptobotrys is 3-porate (Gillespie 1994a, 1994b) (Table 1). Monadelpha shares uneven colpus margins with the 3-colpate taxa. Its tectate-foveolate exine is more similar to the tectate and finely fossulate-reticulate or finely reticulate exines of Gitara and Zuckertia than to the intectate-baculate exine of Tragia sect. Tragia.

Monadelpha is also morphologically distinct, especially its staminate flowers with filaments completely connate into a long cylindrical staminal column bearing a tight terminal cluster of \pm 5 anthers. Acidoton, Bia, Gitara, Platygyna, and Zuckertia all have numerous free stamens, the large Tragia sects. Tragia and Tagira have 3 stamens (sometimes more, to 22) that are distinct or connate only at the base, and T. sect. Leptobotrys has two stamens (rarely 3) connate basally. Only the distantly related Tragia lassia (T. sect. Lassia) of Madagascar has stamens or filaments entirely connate, but this feature has obviously evolved independently. Its androecium, consisting of a small 3-anthered disc-shaped structure on a very short narrow column, is very different from that of Monadelpha.

Other characters of Monadelpha that are unusual for Tragiinae include unisexual inflorescences and long, mostly distinct styles. Whereas most Tragiinae have bisexual inflorescences with pistillate flowers proximal, Monadelpha shares unisexual inflorescences with Gitara and the Caribbean genera Acidoton and Platygyna (plus a few species of Old World Tragiinae). Styles of Monadelpha are slender, cylindrical, mostly smooth (papillose only at the apex), up to $10 \mathrm{~mm}$ long, and connate basally (up to $1 / 4$ their length). Most New World Tragiinae and Old World Tragia have styles that are much shorter, relatively thicker, and basally to mostly connate into a thick stylar 
column. Perhaps most similar is Zuckertia with somewhat longer (to $5 \mathrm{~mm}$ ), slender cylindrical styles that are connate into a slender column, but differ in the degree of connation (1/2-3/4 their length) and the free portion papillose adaxially.

Tragia rubiginosa from Amazonian Peru is another morphologically unusual Tragia species (Huft 1989) that is unplaced in the present sectional classification. The species has 4-colpate pollen (preliminary observations in Gillespie 1994b) and is the only species in Tragiinae other than Monadelpha with a pollen aperture number greater than three. Its broad, thick, subsessile stigmas are unique in Tragiinae and its staminate flowers with five sessile anthers are unusual. The species is morphologically distinct from Monadelpha, and the two taxa are unlikely to be closely related. Molecular data is not yet available to determine its phylogenetic position within Tragiinae.

The isolated phylogenetic position (including a long branch length), and accompanying distinctive stamen and pollen morphology all support the recognition of Monadelpha as a new genus separate from Tragia. Our results suggest a possible relationship with the northern South American and Central American monotypic genus Gitara and the Mexican and Central American ditypic genus Zuckertia.

\section{Taxonomic treatment}

\section{Monadelpha L.J.Gillespie \& Card.-McTeag., gen. nov.}

urn:lsid:ipni.org:names:77213225-1

Tragia section Monadelphae L.J.Gillespie, Novon 4: 331. 1994.

Diagnosis. Similar to Tragia and other Tragiinae genera but differing in having 5-colpate pollen and monadelphous stamens with filaments entirely connate into an elongate, cylindrical staminal column with anthers tightly clustered together at apex.

Type and only known species. Monadelpha guayanensis (L.J.Gillespie) L.J.Gillespie \& Card.-McTeag.

Description. Habit climbing vines, apparently monoecious; latex absent; stems twining; stems, leaves and inflorescences with stinging and simple hairs. Stipules narrowly triangular or lanceolate, small, caducous. Leaves simple, alternate, evergreen, petiolate, eglandular; blades elliptic, ovate-elliptic, broadly elliptic, broadly ovate-elliptic, or suborbicular, chartaceous, apex acuminate, base narrowly cordate, margins irregularly serrulate or denticulate with minute glandular setae, venation pinnate; petiolar and laminar glands absent. Inflorescences slender racemes, unisexual, flowers single per node in bract axil; bracts small, lanceolate or narrowly lanceolate, eglandular; staminate inflorescence axillary; pistillate inflorescence (known only in fruiting stage) terminal but appearing leaf-opposed. Staminate flowers pedicellate; sepals 5, narrowly oblong, valvate; corolla and disc absent; stamens apparently 5, monadelphous; filaments connate into an elongate, \pm cylindrical staminal column, bearing a dense cluster of \pm 5 anthers; pollen 5-colpate, oblate-spheroidal to suboblate, amb pentagonal, exine 
tectate-perforate, tectum foveolate and microverrucate, colpi with uneven margins. Pistillate flowers (description based on old flowers on infructescence axis) pedicellate; sepals 6, ovate, distinctly imbricate, margins entire; corolla and disc absent; ovary 3-locular with 1 ovule per locule, 3-lobed, densely covered with stinging hairs; styles 3 , long-cylindrical, mostly distinct, connate basally for 10-25\% length, papillose at apex. Fruits 3-lobed capsules, dehiscing into 3 bivalved mericarps; pericarp woody, sparsely covered with stinging hairs; columella persistent, with 3 perpendicular apical arms; seeds 3, subglobose, abaxial surface somewhat obtusely angular, ecarunculate; sepals persistent.

Etymology. The genus name is combined from monos (Greek, one) and adelphos (Greek, brother), and refers to monadelphous with filaments united and to Tragia section Monadelphae.

\section{Monadelpha guayanensis (L.J.Gillespie) L.J.Gillespie \& Card.-McTeag., comb. nov.} urn:lsid:ipni.org:names:77213226-1

Figures 1, 2

Tragia guayanensis L.J.Gillespie, Novon 4: 330-338. 1994.

Type. Venezuela. Amazonas: Río Casiquiare entre la boca del [Rio] Siapa y el caño Momoni, 18 Feb-4 Mar 1986, B. Stergios \& G. Aymard 9182 (holotype: MO-260419! - staminate; isotype: NY-00076710! - pistillate).

Description. See Gillespie (1994b). Emended here (based on Ule 5013): Leaves: petiole $2-8 \mathrm{~cm}$ long, blade elliptic, ovate-elliptic, broadly elliptic, broadly ovate-elliptic, or suborbicular, $12-25 \times 6-17 \mathrm{~cm}$, apex with acumen 1-2 cm long, base cordate with narrow sinus $0.8-2.5 \mathrm{~cm}$ deep, margins irregularly serrulate or denticulate. Staminate inflorescences $-3-18 \mathrm{~cm}$ long.

Etymology. The specific epithet is derived from Guayana, and refers both to the Guayana Shield region of northern South America and to the Guayana Region of Venezuela where the species is native. Guayana is of Amerindian derivation by European colonists, and may come from the tribe Guayanos or the Indigenous word uayana, meaning pale (see Berry et al. 1995).

Additional collections examined. Brazil. Amazonas: Rio Juruá, Nov 1900, E.H.G. Ule 5013 (L-0160690, K-001205092). Venezuela. Amazonas: En la isla de

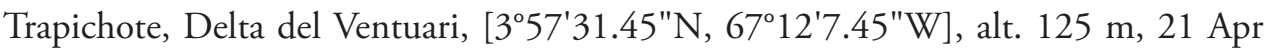
1942, L. Williams 14990 (paratypes: F-1189188, US-1833601).

Distribution and preliminary conservation status. Known from only three collections. The two from Venezuela are $-220 \mathrm{~km}$ apart in lowland rainforests of the upper Orinoco Basin and Río Casiquiare of western Amazonas. The Brazilian collection occurs at least $500 \mathrm{~km}$ to the south along the Rio Juruá (locality imprecise) in Amazonas. They occur in remote, pristine rainforest and their IUCN Red List Category presently should be Data Deficient given limited information of distribution and threats. 


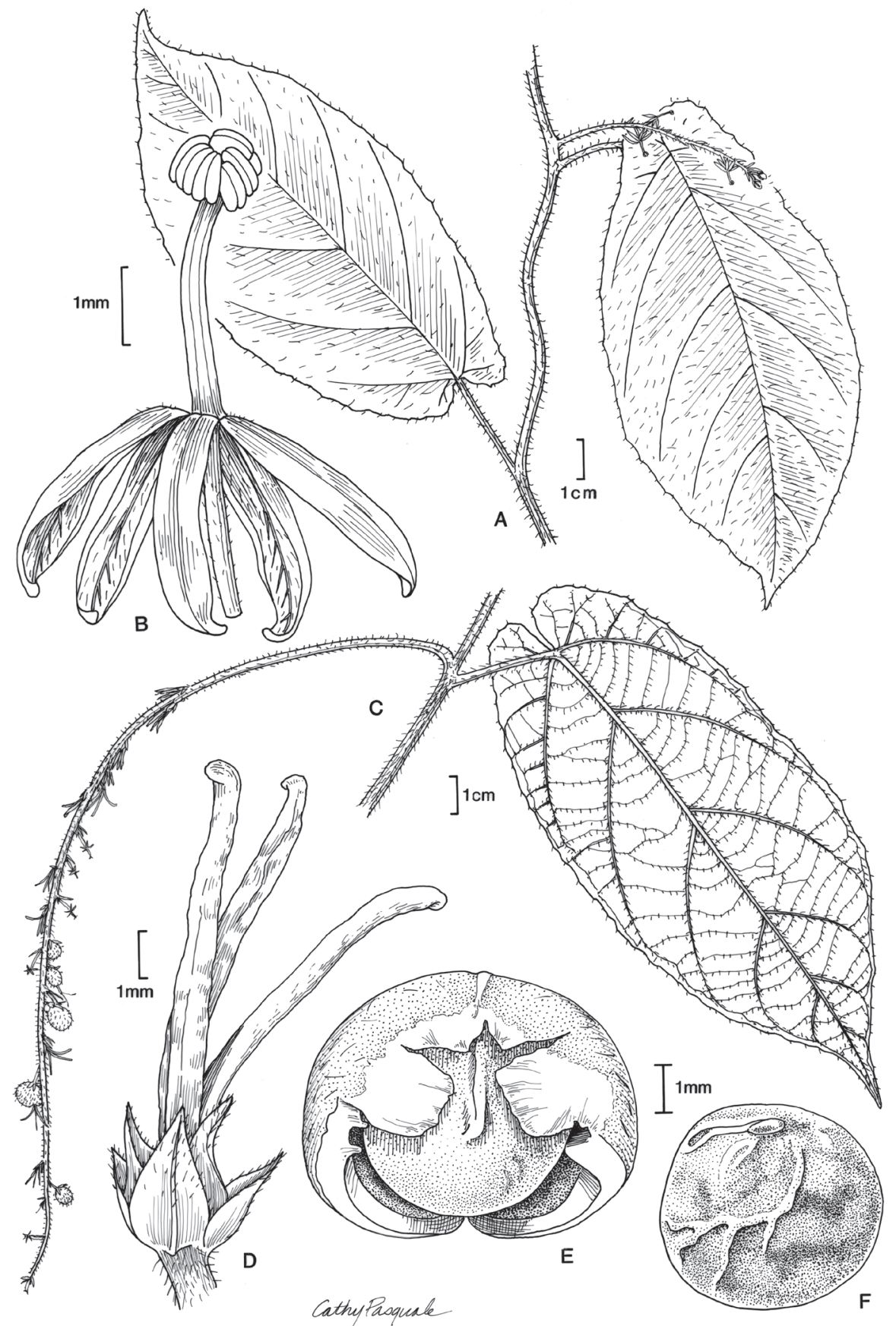

Figure I. Illustration of Monadelpha guayanensis. A habit showing staminate inflorescence B staminate flower $\mathbf{C}$ habit showing infructescence $\mathbf{D}$ pistillate flower $\mathbf{E}$ mericarp of dehisced capsule with enclosed seed $\mathbf{F}$ seed, lateral view with hilum at top. Sources: A, B based on Stergios \& Aymard 9182 (MO) C-F based on Stergios \& Aymard 9182 (NY). Illustration by Cathy Pasquale reproduced from Gillespie (1994b) with permission from the Missouri Botanical Garden Press. 

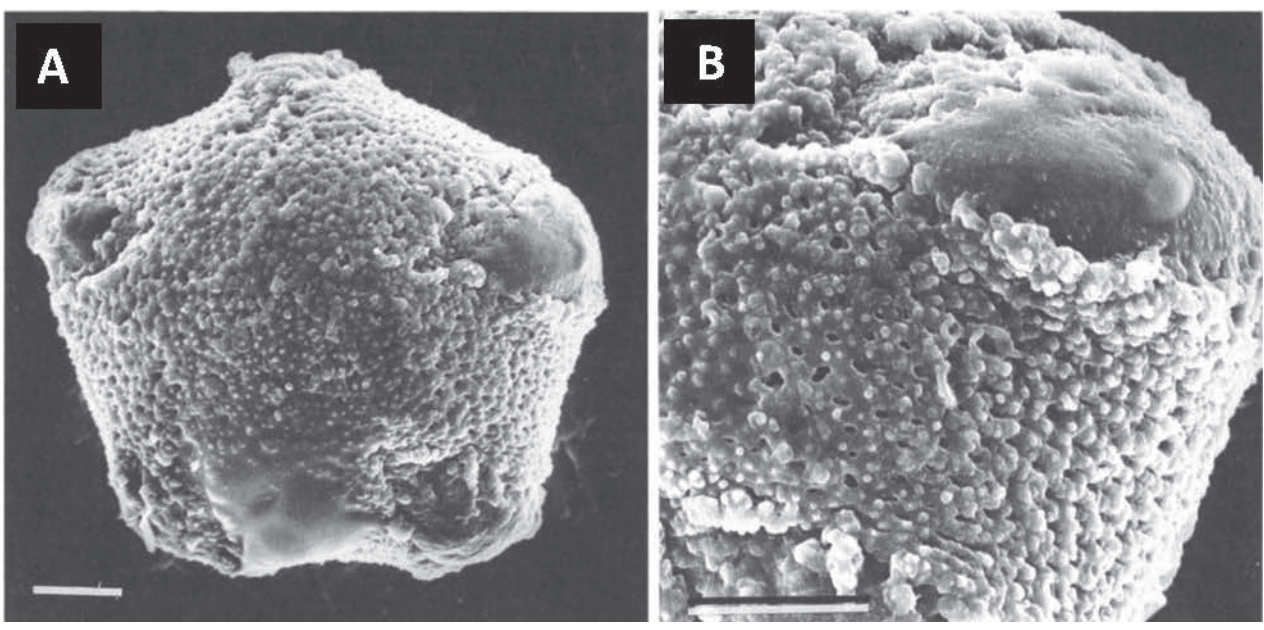

Figure 2. Pollen morphology of Monadelpha guayanensis A SEM of pollen grain showing polar view with five colpi B closeup of mesocolpium and two colpi. Source: Stergios \& Aymard 9182 (MO). Figure reproduced from Gillespie (1994b) with permission from the Missouri Botanical Garden Press.

Notes. Monadelpha guayanensis is newly reported here from Brazil based on one 1900 collection by E.H.G. Ule. Staminate inflorescences on this collection (L-0160690 sheet) are considerably longer than previously described, and are closer in length to the pistillate inflorescence. It appears that the staminate inflorescence on the holotype may be damaged and partly missing or possibly less mature. Leaf blades are more variable in size and shape than on the two Venezuelan collections, some blades being very similar, others larger and relatively broader.

Monadelpha guayanensis has unisexual inflorescences and is likely monoecious (rather than dioecious). Although unisexual inflorescences are not found on the same branch, the type collection, Stergios \& Aymard 9182, has inflorescences of both sexes, and is thus monoecious if one assumes branches originate from a single individual. Further collections are needed to confirm this character.

\section{Key to Tragiinae in South America and Central America}

1 Filaments absent or entirely connate into an elongate staminal column; pollen 4- or 5-colpate; inflorescences unisexual, racemose; staminate flowers with 5 sepals and 5 stamens

- $\quad$ Filaments distinct or rarely partly connate; pollen 3-colpate, weakly 3-porate, or inaperturate; inflorescences bisexual (unisexual in Gitara), racemose or paniculate with a single branch; staminate flowers with 3-5 (6) sepals and (1) $2-40+$ stamens

2 Anthers in a dense cluster on an elongate \pm cylindrical staminal column; pollen 5-colpate; styles cylindrical, 6-10 $\mathrm{mm}$ long.

- $\quad$ Anthers sessile; pollen 4-colpate; stigmas subsessile, broad... Tragia rubiginosa 


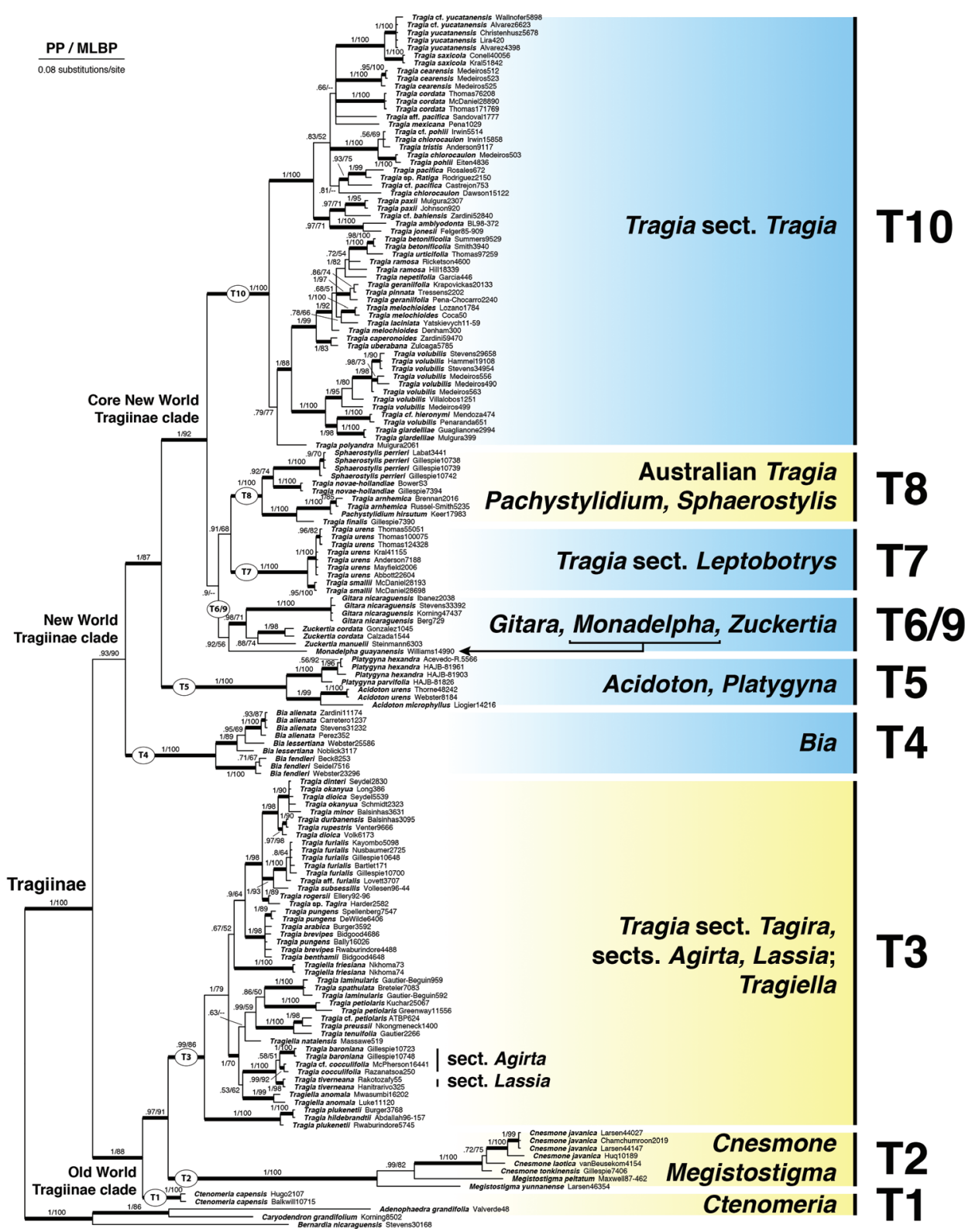

Figure 3. Phylogenetic relationships of Monadelpha. Bayesian 50\% majority rule consensus tree for the 159-accession (80 taxa) ITS dataset of Tragiinae, demonstrating the distinct phylogenetic placement of Monadelpha (subclade T6/9). Subclade naming system follows Cardinal-McTeague and Gillespie (2016) with minor adjustments. Branches are labeled with Bayesian posterior probabilities (PP) and maximum likelihood bootstrap percentages (MLBP). Bold branches indicate strong support ( $\mathrm{PP}>0.95, \mathrm{MLBP}>85$ ) and coloured boxes indicate general distribution (New World = blue, Old World = yellow). 
3 Inflorescences unisexual; dioecious, erect shrubs; anther connective with tuft of stinging hairs

Gitara

- Inflorescences bisexual with pistillate flowers basal; monecious vines, herbs, or subshrubs; anther connective lacking tuft of stinging hairs or present but

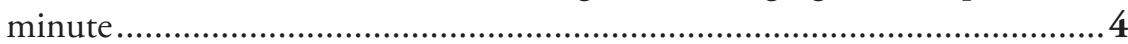

4 Inflorescences racemose, with 1 (2) pistillate flower(s) at the basal $1(-9)$ node(s) (T. polyandra with (1) 2-4 (5) flowers on a short basal branch); stamens (1) 2-5 (-22); staminate disc usually absent, if present comprising a single central structure; pollen exine intectate, baculate Tragia (sect. Tragia)

- Inflorescences consisting of a racemose staminate main axis and a single elongate basal branch bearing 5-30 pistillate flowers (branch short with (1) 2-4 flowers in Zuckertia manuelii); stamens 6-40+; staminate disc segmented or absent; pollen exine tectate, finely reticulate or foveolate-fossulate

5 Staminate flowers with 3 (4) sepals, 5-10 disc segments, and 6-20 stamens; leaf blades 5-16 cm long, usually unlobed; pollen inaperturate; South America to Costa Rica Bia

- $\quad$ Staminate flowers with 5 or 6 sepals, no disc, and 17-40+ stamens; leaf blades (7-) 12-25 cm long, unlobed to 3-lobed; pollen tricolpate; Mexico and Central America.

Zuckertia

\section{Acknowledgements}

We thank the Missouri Botanical Garden Press, St. Louis, for granting permission to reproduce Figures 1, 2, and 7 from Gillespie (1994b: 332, 334). The laboratory work was conducted with support of the Molecular Biodiversity Laboratory of the Canadian Museum of Nature and the Smithsonian's Laboratories of Analytical Biology of the National Museum of Natural History. We thank Kanchi Gandhi (GH) for advice on orthography, Geoff Levin, Paul Berry, Gordon McPherson and an anonymous reviewer for helpful comments on the manuscript, and the following institutions for the loan of material or for facilitating examination of collections: MO, NY, P and US. This work was supported by the Canadian Museum of Nature.

\section{References}

Baillon H (1858) Étude Générale du Groupe des Euphorbiacées. V. Masson, Paris.

Berry PE, Holst BK, Yatskievych K (1995) Introduction. In: Berry PE, Holst BK, Yatskievych K (Eds) Flora of the Venezuelan Guayana. Volume 1: Introduction. Missouri Botanical Garden \& Timber Press, Portland, xv-xxii.

Cardinal-McTeague WM, Gillespie LJ (2016) Molecular phylogeny and pollen evolution of Euphorbiaceae tribe Plukenetieae. Systematic Botany 41(2): 329-347. https://doi. org/10.1600/036364416X691759 
Cardinal-McTeague WM, Wurdack KJ, Sigel EM, Gillespie LJ (2019) Seed size evolution and biogeography of Plukenetia (Euphorbiaceae), a pantropical genus with traditionally cultivated oilseed species. BMC Evolutionary Biology 19(1): 29. https://doi.org/10.1186/s12862-018-1308-9

Cervantes A, Fuentes S, Gutiérrez J, Magallón S, Borsch T (2016) Successive arrivals since the Miocene shaped the diversity of the Caribbean Acalyphoideae (Euphorbiaceae). Journal of Biogeography 43(9): 1773-1785. https://doi.org/10.1111/jbi.12790

Darriba D, Taboada GL, Doallo R, Posada D (2012) jModelTest 2: More models, new heuristics and parallel computing. Nature Methods 9(8): 772. https://doi.org/10.1038/nmeth.2109

Dorr LJ, Romero-Hernández C, Wurdack KJ (2018) A new large-flowered species of Andeimalva (Malvaceae, Malvoideae) from Peru. PhytoKeys 110: 91-99. https://doi.org/10.3897/ phytokeys. 110.29376

Gillespie LJ (1994a) Pollen morphology and phylogeny of the tribe Plukenetieae (Euphorbiaceae). Annals of the Missouri Botanical Garden 81(2): 317-348. https://doi. org/10.2307/2992101

Gillespie LJ (1994b) A new section and two new species of Tragia (Euphorbiaceae) from the Venezuelan Guayana and French Guiana. Novon 4(4): 330-338. https://doi. org/10.2307/3391440

Huft MJ (1989) New and critical taxa of Euphorbiaceae from South America. Annals of the Missouri Botanical Garden 76(4): 1077-1086. https://doi.org/10.2307/2399692

Katoh K, Standley D (2013) MAFFT multiple sequence alignment software version 7: Improvements in performance and usability. Molecular Biology and Evolution 30(4): 772-780. https://doi.org/10.1093/molbev/mst010

Leandri JD (1971) Un sous-genre malgache nouveau de Tragia (Euphorbiacées). Adansonia, sér. 2 11: 435-439.

Medeiros D, de Senna Valle L, Valka Alves RJ (2013) Revalidation of the genera Bia and Zuckertia (Euphorbiaceae) with B. capivarensis sp. nov. from Serra da Capivara, Brazil. Nordic Journal of Botany 31(5): 595-602. https://doi.org/10.1111/j.1756-1051.2012.01616.x

Miller MA, Pfeiffer W, Schwartz T (2010) Creating the CIPRES Science Gateway for inference of large phylogenetic trees. Proceedings of the 2010 Gateway Computing Environments Workshop (GCE), New Orleans, 1-8. https://doi.org/10.1109/GCE.2010.5676129

Mulgura de Romero M, Gutierrez de Sanguinetti M (1989) Actualizacion taxonomica de Tragia (Euphorbiaceae) para Argentina y regiones limitrofes. Darwiniana 29(1-4): 77-138.

Radcliffe-Smith A (2001) Genera Euphorbiacearum. Royal Botanic Gardens, Kew.

Rambaut A, Drummond A, Xie D, Baele G, Suchard M (2018) Posterior summarization in Bayesian phylogenetics using Tracer 1.7. Systematic Biology 67(5): 901-904. https://doi. org/10.1093/sysbio/syy032

Ronquist F, Teslenko M, van der Mark P, Ayres DL, Darling A, Höhna S, Larget B, Liu L, Suchard MA, Huelsenbeck JP (2012) MrBayes 3.2: Efficient Bayesian phylogenetic inference and model choice across a large model space. Systematic Biology 61(3): 539-542. https://doi.org/10.1093/sysbio/sys029

Stamatakis A (2014) RAxML version 8: A tool for phylogenetic analysis and post-analysis of large phylogenies. Bioinformatics (Oxford, England) 30(9): 1312-1313. https://doi. org/10.1093/bioinformatics/btu033 
Steinmann VW, Ramírez-Amezcua Y (2013) Bia manuelii (Euphorbiaceae: Acalyphoideae), a new species from Sierra de Coalcomán, Michoacán, Mexico. Revista Mexicana de Biodiversidad 84(3): 746-750. https://doi.org/10.7550/rmb.32014

Webster GL (2007) Taxonomic and nomenclatural changes in American Euphorbiacaeae sensu lato. Contributions from the University of Michigan Herbarium 25: 235-239.

Webster GL (2014) Euphorbiaceae. In: Kubitzki K (Ed.) The Families and Genera of Vascular Plants. Volume XI. Flowering Plants. Eudicots. Malpighiales. Springer Verlag, Berlin and Heidelberg, Germany, 51-216. https://doi.org/10.1007/978-3-642-39417-1_10

Wurdack KJ, Hoffmann P, Chase MW (2005) Molecular phylogenetic analysis of uniovulate Euphorbiaceae (Euphorbiaceae sensu stricto) using plastid $r b c L$ and $\operatorname{trn} L-F$ DNA sequences. American Journal of Botany 92(8): 1397-1420. https://doi.org/10.3732/ajb.92.8.1397

\section{Appendix I}

Sources for ITS data used in phylogenetic analyses. Voucher data (country, collector, number, herbarium code) are provided, with new GenBank numbers in bold and beginning with $\mathrm{MK}$ and $\mathrm{MW}$.

Outgroup: Adenophaedra grandifolia (Klotzsch) Müll.Arg. CosTA Rica • Valverde 48 (NY), MK780909. Bernardia nicaraguensis Standl. \& L.O.Williams Nicaragua • Stevens 30168 (MO), KP794419. Caryodendron grandifolium (Müll.Arg.) Pax Ecuador - Korning 8502 (MO), KP794421. Ingroup: Acidoton microphyllus Urban Dominican Republic • Liogier 14216 (NY), MK780907. Acidoton urens Sw. Jamaica • Thorne 48242 (MO), KP794316. Acidoton urens Sw. JamaICA • Webster 8184 (DAV), MK780908. Bia alienata Didr. Bolivia • Carretero 1237 (MO), KP794320. Bia alienata Didr. Paraguay • Pérez 352 (MO), KP794318. Bia alienata Didr. Paraguay • Stevens et al. 31232 (MO), MK780928. Bia alienata Didr. ParaguaY • Zardini 11174 (MO), KP794319. Bia fendleri Müll.Arg. BolrviA • Beck 8253 (MO), KP794321. Bia fendleri Müll.Arg. ParaguaY • Seidel and Herzog 7516 (DAV), MK780930. Bia fendleri Müll.Arg. Peru • Webster 23296 (DAV), MK780929. Bia cf. lessertiana BrazIL • Noblick 3117 (DAV), MK780931. Bia lessertiana Baill. BrazIL • Webster 25586 (DAV), MK780932. Cnesmone javanica Blume Bangladesh • Huq 10189 (US), MK780937. Cnesmone javanica Blume Thailand - Chamchumroon 2019 (L), KP794430. Cnesmone javanica Blume ThaIland • Larsen 44027 (MO), KP794427. Cnesmone javanica Blume ThaILAnd • Larsen 44147 (MO), KP794428. Cnesmone laotica (Gagnep.) Croizat ThaIland • van Beusekom 4154 (L), KP794431. Cnesmone tonkinensis (Gagnep.) Croizat VIETNAM • Gillespie 7406 (CAN), MK780938. Ctenomeria capensis (Thunb.) Harv. ex Sond. South Africa • Balkwill and Balkwill 10715 (MO), MK780939. Ctenomeria capensis (Thund.) Harv. ex Sond. South Africa • Hugo 2107 (MO), KP794322. Gitara nicaraguensis (Hemsl.) Card.-McTeag. \& L.J.Gillespie Brazil • Berg et al. 729 (CAN), MK780953. Gitara nicaraguensis (Hemsl.) Card.-McTeag. \& L.J.Gillespie Ecuador • Korning 47437 (MO), KP794398. 
Gitara nicaraguensis (Hemsl.) Card.-McTeag. \& L.J.Gillespie Nicaragua - Stevens 33392 (MO), MK780954. Gitara nicaraguensis (Hemsl.) Card.-McTeag. \& L.J.Gillespie Panama - Ibañez 2038 (MO), KP794397. Megistostigma peltatum (J.J.Sm.) Croizat Thailand • Maxwell 87-462 (L), MK780958. Megistostigma yunnanense Croizat ThaILAND $\bullet$ Larsen 46354 (L), MK780959. Monadelpha guayanensis (L.J.Gillespie) L.J.Gillespie \& Card.-McTeag. Venezuela • Williams 14990 (US1833601), MW264490. Pachystylidium hirsutum (Blume) Pax \& K. Hoffm. Thailand - Keer 17893 (L), KP794408. Platygyna hexandra (Jacq.) Müll.Arg. Cuba • AcevedoRodríguez 5566 (NY), KP794317. Platygyna hexandra (Jacq.) Müll.Arg. CuBA • HAJB 81903 (MICH), MK780963. Platygyna hexandra (Jacq.) Müll.Arg. Cuba • HAJB 81961 (MICH), MK780964. Platygyna parvifolia Alain CuBA • HAJB 81826 (MICH), MK780965. Sphaerostylis perrieri Leandri MADAGASCAR • Gillespie 10738 (CAN), KP794413. Sphaerostylis perrieri Leandri MadAGASCAR • Gillespie 10739 (CAN), KP794414. Sphaerostylis perrieri Leandri MadaGaSCAR • Gillespie 10742 (CAN), KP794415. Sphaerostylis perrieri Leandri MadAGasCaR • Labat 3441 (MO), KP794412. Tragia aff. furialis TANZANIA • Lovett 3707 (MO), KP794344. Tragia aff. pacifica EL SALVADOR • Sandoval 1777 (MO), KP794388. Tragia amblyodonta (Müll. Arg.) Pax \& K.Hoffm. USA • B.L. 98-372 (MO), KP794376. Tragia arabica (Müll. Arg.) Baill. ex Prain Ethiopia • Burger 3592 (US), MK780910. Tragia arnhemica P.I.Forst. Australia • Brennan 2016 (DNA), KP794410. Tragia arnhemica P.I.Forst. Australia • Russel-Smith 5235 (DNA), KP794409. Tragia baroniana Prain MadAGASCAR • Gillespie et al. 10723 (CAN), MK780911. Tragia baroniana Prain MAdAGASCAR • Gillespie et al. 10748 (CAN), MK780912. Tragia benthamii Baker TANZANIA • Bidgood 4648 (MO), KP794328. Tragia betonicifolia Nutt. USA • Smith 3940 (MO), KP794364. Tragia betonicifolia Nutt. USA • Summers 9529 (MO), KP794363. Tragia brevipes Pax TANZANIA • Bidgood 4686 (MO), KP794325. Tragia brevipes Pax Uganda - Rwaburindore 4488 (MO), KP794329. Tragia caperonoides Pax \& K. Hoffm. Paraguay • Zardini and Gamarra 59470 (MO), MK780967. Tragia cearensis Pax \& K.Hoffm. BraziL $\bullet$ Medeiros et al. 512 (R), MK780968. Tragia cearensis Pax \& K.Hoffm. BrazIL - Medeiros et al. 523 (R), MK780969. Tragia cearensis Pax \& K.Hoffm. BrazIL • Medeiros et al. 525 (R), MK780970. Tragia cf. bahiensis ParaguaY - Zardini 52840 (MO), KP794378. Tragia cf. cocculifolia MadaGasCAR • McPherson and van der Werff 16441 (CAN), MK780913. Tragia cf. hieronymi Bolivia $\bullet$ Mendoza 474 (NY), MK780975. Tragia cf. pacifica Mexico • Castrejón 753 (MO), KP794392. Tragia cf. petiolaris UGANDA - ATBP 624 (MO), KP794351. Tragia cf. pohlii BrazIL • Irwin 5514 (NY), MK780971. Tragia cf. yucatanensis MeXICO • Álvarez 6623 (MO), KP794383. Tragia cf. yucatanensis Guatemala • Wallnöfer 5898 (MO), KP794381. Tragia chlorocaulon Baill. BrazIL • Dawson 15122 (MO), KP794390. Tragia chlorocaulon Baill. BrAzIL • Irwin 15858 (MO), KP794391. Tragia chlorocaulon Baill. BraziL • Medeiros et al. 503 (R), MK780973. Tragia cocculifolia Prain Madagascar • Razanatsoa 250 (MO), KP794331. Tragia cordata Michx. USA • McDaniel 28890 (MO), KP794395. Tragia cordata Michx. USA • Thomas 171769 (MO), KP794396. Tragia cordata Michx. USA • Thomas 76208 (CAN), KP794394. 
Tragia dinteri Pax Namibia - Seydel 2830 (L), MK780914. Tragia dioica Sond. NAmibia • Seydel 5539 (MO), KP794335. Tragia dioica Sond. Namibia • Volk 6173 (MO), KP794332. Tragia durbanensis Kuntze South Africa • Balsinhas 3095 (MO), KP794333. Tragia finalis P.I.Forst. Australia • Gillespie 7390 (CAN), KP794411. Tragia furialis Bojer ex Prain Madagascar • Gillespie 10648 (CAN), KP794342. Tragia furialis Bojer ex Prain MadagascaR • Gillespie 10700 (CAN), MK780917. Tragia furialis Bojer ex Prain Madagascar • Nusbaumer 2725 (MO), KP794343. Tragia furialis Bojer ex Prain Mayotte • Barthlet 171 (MO), KP794341. Tragia furialis Bojer ex Prain TAnzania • Kayombo 5098 (MO), KP794340. Tragia geraniifolia Klotzsch ex Baill. Argentina • Krapovickas 20133 (MO), KP794368. Tragia geraniifolia Klotzsch ex Baill. Paraguay • Peña-Chocarro 2240 (MO), KP794370. Tragia giardelliae M.M.Gutiérrez \& M.E.Múlgura Argentina • Guaglianone 2994 (MO), KP794360. Tragia giardelliae M.M.Gutiérrez \& M.E.Múlgura Argentina • Mulgura 399 (NY), MK780974. Tragia hildebrandtii Müll.Arg. TAnZania - Abdallah 96/157 (MO), KP794355. Tragia jonesii Radcl.-Sm. \& Govaerts Mexico • Felger 85-909 (MO), KP794377. Tragia laciniata (Torr.) Müll.Arg. Mexico • Yatskievych 11-59 (MO), MK780976. Tragia laminularis Müll.Arg. Côte D’Ivorre • Gautier-Béguin 592 (MO), KP794349. Tragia laminularis Müll.Arg. Côte D’Ivoıre • Gautier-Béguin 959 (MO), KP794348. Tragia melochioides Griseb. Bolivia • Coca 50 (MO), KP794373. Tragia melochioides Griseb. Bolivia • Lozano 1784 (MO), KP794372. Tragia melochioides Griseb. URuguaY • Denham et al. 300 (SI), MK780978. Tragia mexicana Müll.Arg. Belize • Peña 1029 (MO), KP794393. Tragia minor Sond. South Africa - Balsinhas 3631 (MO), KP794338. Tragia nepetifolia Cav. Mexico • García 446 (MO), KP794366. Tragia novae-hollandiae Müll.Arg. Australia • Bower S3 (CAN), MK780960. Tragia novae-hollandiae Müll.Arg. Australia • Gillespie 7394 (CAN), KP794417. Tragia okanyua Pax Botswana - Long 386 (MO), KP794336. Tragia okanyua Pax ZAMBiA • Schmidt 2323 (MO), KP794337. Tragia pacifica McVaugh EL SAlvador • Rosales 672 (MO), KP794389. Tragia paxii Lourteig \& O’Donnell ARGentina • Johnson 920 (MO), KP794380. Tragia paxii Lourteig \& O’Donnell ARGentina • Múlgura 2307 (MO), KP794379. Tragia petiolaris Radcl.-Sm. Tanzania • Greenway and Polhill 11556 (L), MK780920. Tragia petiolaris Radcl.-Sm. Tanzania - Kuchar 25067 (MO), KP794354. Tragia pinnata (Poir.) A.Juss. Argentina • Tressens 2202 (MO), KP794369. Tragia plukenetii Radcl.-Sm. EтніоріA • Burger 3768 (US), MK780919. Tragia plukenetii Radcl.-Sm. UGANDA - Rwaburindore 5745 (MO), KP794356. Tragia pohlii Müll.Arg. BrazIL • Eiten 4836 (UBC), MK780979. Tragia polyandra Vell. Argentina • Múlgura 2061 (MO), KP794375. Tragia preussii Pax Cameroon • Nkongmeneck 1400 (MO), KP794352. Tragia pungens (Forssk.) Müll. Arg. Eтhiopia • De Wilde 6406 (MO), KP794327. Tragia pungens (Forssk.) Müll.Arg. Somalia • Bally 16026 (MO), KP794326. Tragia pungens (Forssk.) Müll.Arg. YemeN - Spellenberg 7547 (L), MK780921. Tragia ramosa Torr. USA • Hill 18339 (MO), KP794371. Tragia ramosa Torr. USA • Ricketson 4600 (MO), KP794367. Tragia rogersii Prain South Africa - Ellery 92/96 (MO), KP794339. Tragia rupestris Sond. South Africa • Venter 9666 (MO), KP794334. Tragia saxicola Small USA • Conell 
40056 (MO), KP794386. Tragia saxicola Small USA • Kral 51842 (MO), KP794387. Tragia smallii Shinners USA - McDaniel 28193 (MO), KP794401. Tragia smallii Shinners USA • McDaniel 28698 (MO), KP794402. Tragia sp. Ratiga EL SAlvador • Rodriguez and Tejada 2150 (MO), MK780980. Tragia sp. Tagira Zambia • Harder and Bingham 2582 (CAN), MK780923. Tragia spathulata Benth. Togo • Breteler 7083 (MO), KP794350. Tragia subsessilis Pax Tanzania • Vollesen 96/44 (MO), KP794345. Tragia tenuifolia Benth. Côte D’Ivorre • Gautier 2266 (MO), KP794353. Tragia tiverneana Leandri MADAGASCAR • Hanitrarivo 325 (CAN), MK780925. Tragia tiverneana Leandri MADAGASCAR • Rakotozafy et al. 55 (CAN), MK780924. Tragia tristis Müll.Arg. BrazIL • Anderson 9117 (NY), MK780981. Tragia uberbana Müll.Arg. Argentina • Zuloaga 5785 (MO), KP794374. Tragia urens L. USA • Abbott 22604 (MO), MK780957. Tragia urens L. USA • Anderson 7188 (MO), KP794407. Tragia urens L. USA • Kral 41155 (MO), KP794406. Tragia urens L. USA - Mayfield 2006 (MO), MK780956. Tragia urens L. USA • Thomas 100075 (MO), KP794404. Tragia urens L. USA • Thomas 124328 (MO), KP794405. Tragia urens L. USA • Thomas 55051 (CAN), KP794403. Tragia urticifolia Michx. USA • Thomas 97259 (CAN), KP794365. Tragia volubilis L. Bolıvia • Peñarando et al. 651 (MO), MK780987. Tragia volubilis L. Bolivia • Villalobos et al. 1251 (MO), MK780988. Tragia volubilis L. BRAzIL • Medeiros and Cardinal-McTeague 556 (R), MK780984. Tragia volubilis L. BrazIL • Medeiros and Cardinal-McTeague 563 (R), MK780985. Tragia volubilis L. BrazIL • Medeiros et al. 490 (R), MK780983. Tragia volubilis L. BraziL • Medeiros et al. 499 (R), MK780982. Tragia volubilis L. Costa RiCa • Hammel 19108 (MO), KP794362. Tragia volubilis L. Nicaragua • Stevens 29658 (MO), KP794361. Tragia volubilis L. Nicaragua - Stevens and Montiel 34954 (MO), MK780986. Tragia yucatanensis Millsp. Guatemala - Christenhusz 5678 (MO), KP794384. Tragia yucatanensis Millsp. Mexico • Alvarez 4398 (MO), KP794382. Tragia yucatanensis Millsp. Mexico • Lira 420 (MO), KP794385. Tragiella anomala (Prain) Pax \& K.Hoffm. Tanzania • Luke 11120 (MO), KP794324. Tragiella anomala (Prain) Pax \& K.Hoffm. TanZania • Mwasumbi 16202 (MO), KP794323. Tragiella friesiana (Prain) Pax \& K.Hoffm. ZAMBIA $\bullet$ Nkhoma 73 (MO), KP794346. Tragiella friesiana (Prain) Pax \& K.Hoffm. Zambia • Nkhoma 74 (MO), KP794347. Tragiella natalensis (Sond.) Pax \& K.Hoffm. TANZANiA • Massawe 519 (MO), KP794330. Zuckertia cordata Baill. Costa Rica • González 1045 (MO), KP794399. Zuckertia cordata Baill. Mexico • Calzada 1544 (MO), KP794400. Zuckertia manuelii (V.W.Steinm. \& Ram.-Amezcua) Card.-McTeag. \& L.J.Gillespie Mexico • Steinmann et al. 6303 (CAN), MK780989. 